\title{
Characterization of the bark storage protein gene (UCBSP) family in the perennial woody plant Jatropha curcas and the function of JCBSP1 in Arabidopsis thaliana
}

\author{
Ming-Jun Zhang ${ }^{1,2}$, Qiantang Fu ${ }^{2}$, Mao-Sheng Chen ${ }^{2}$, Huiying He ${ }^{2}$, Mingyong Tang ${ }^{2}$, Jun Ni $^{3}$, Yan-Bin Tao ${ }^{\text {Corresp., }}{ }^{2}$, \\ Zeng-Fu Xu Corresp. 2, 3 \\ 1 \\ ${ }^{1}$ School of Life Sciences, University of Science and Technology of China, Hefei, Anhui, China \\ 2 CAS Key Laboratory of Tropical Plant Resources and Sustainable Use, Xishuangbanna Tropical Botanical Garden, The Innovative Academy of Seed \\ Design, Chinese Academy of Sciences, Menglun, Mengla, Yunnan, China \\ 3 \\ State Key Laboratory for Conservation and Utilization of Subtropical Agro-Bioresources, College of Forestry, Guangxi University, Nanning, Guangxi, China \\ Corresponding Authors: Yan-Bin Tao, Zeng-Fu Xu \\ Email address: taoyanbin@xtbg.ac.cn, zfxu@xtbg.ac.cn
}

Background. Bark storage protein (BSP) plays an important role in seasonal nitrogen cycling in perennial deciduous trees. However, there is no report on the function of BSP in the perennial woody oil plant Jatropha curcas.

Methods. In this study, we identified six members of JCBSP gene family in J. curcas genome. The patterns, seasonal changes, and responses to nitrogen treatment in gene expression of JcBSPs were detected by quantitative reverse transcription-polymerase chain reaction (qRT-PCR). Overexpression of JCBSP1 in transgenic Arabidopsis thaliana was driven by a constitutive cauliflower mosaic virus (CaMV) 35S RNA promoter.

Results. JCBSP members were found to be expressed in various tissues, except seeds. The seasonal changes in the total protein concentration and JCBSP1 expression in the stems of J. curcas were positively correlated, as both increased in autumn and winter and decreased in spring and summer. In addition, the JCBSPI expression in J. curcas seedlings treated with different concentrations of an $\mathrm{NH}_{4} \mathrm{NO}_{3}$ solution was positively correlated with the $\mathrm{NH}_{4} \mathrm{NO}_{3}$ concentration and application duration. Furthermore, JCBSPI overexpression in Arabidopsis resulted in a phenotype of enlarged rosette leaves, flowers, and seeds, and significantly increased the seed weight and yield in transgenic plants. 
1 Characterization of the bark storage protein gene

2 (JcBSP) family in the perennial woody plant Jatropha

3 curcas and the function of JcBSP1 in Arabidopsis

4 thaliana

6 Ming-Jun Zhang ${ }^{1,2}$, Qiantang $\mathrm{Fu}^{2}$, Mao-Sheng Chen ${ }^{2}$, Huiying $\mathrm{He}^{2}$, Ming-Yong Tang ${ }^{2}$, Jun $\mathrm{Ni}$

$7 \quad{ }^{3}$, Yan-Bin $\mathrm{Tao}^{2}$ and Zeng-Fu Xu ${ }^{2,3}$

$8{ }^{1}$ School of Life Sciences, University of Science and Technology of China, Hefei, 230022, China

$9 \quad{ }^{2}$ CAS Key Laboratory of Tropical Plant Resources and Sustainable Use, Xishuangbanna

10 Tropical Botanical Garden, The Innovative Academy of Seed Design, Chinese Academy of

11 Sciences, Menglun, Mengla, 666303, China

$12{ }^{3}$ State Key Laboratory for Conservation and Utilization of Subtropical Agro-Bioresources,

13 College of Forestry, Guangxi University, Nanning, 530004, China

14

Corresponding authors:

16 Yan-Bin Tao, taoyanbin@xtbg.ac.cn

17 Zeng-FuXu, zfxu@gxu.edu.cn

\section{Abstract}

Background. Bark storage protein (BSP) plays an important role in seasonal nitrogen cycling in perennial deciduous trees. However, there is no report on the function of BSP in the perennial woody oil plant Jatropha curcas.

Methods. In this study, we identified six members of $J c B S P$ gene family in $J$. curcas genome. The patterns, seasonal changes, and responses to nitrogen treatment in gene expression of $J c B S P$ s were detected by quantitative reverse transcription-polymerase chain reaction (qRT-PCR). Overexpression of JCBSP1 in transgenic Arabidopsis thaliana was driven by a constitutive cauliflower mosaic virus (CaMV) 35S RNA promoter.

Results. $J c B S P$ members were found to be expressed in various tissues, except seeds. The seasonal changes in the total protein concentration and $J C B S P 1$ expression in the stems of $J$. curcas were positively correlated, as both increased in autumn and winter and decreased in spring and summer. In addition, the $J c B S P 1$ expression in $J$. curcas seedlings treated with different concentrations of an $\mathrm{NH}_{4} \mathrm{NO}_{3}$ solution was positively correlated with the $\mathrm{NH}_{4} \mathrm{NO}_{3}$ concentration and application duration. Furthermore, JcBSP1 overexpression in Arabidopsis resulted in a phenotype of enlarged rosette leaves, flowers, and seeds, and significantly increased the seed weight and yield in transgenic plants.

\section{Introduction}

Seasonal nitrogen cycling (SNC) is important in deciduous perennials to ensure the sufficient use of nitrogen resources. It is also a decisive factor for plant fitness in perennial (May \& Killingbeck 1992). The process of SNC involves the degradation of proteins when leaves shed in 
41

42

43

44

45

46

47

48

49

50

51

52

53

54

55

56

57

58

59

60

61

62

63

64

65

66

67

68

69

70

71

72

73

74

75

76

77

78

79

80

81

82

83

84

85

86

autumn, the transportation of the released amino acids to the perennial tissues (bark and wood) to synthesize storage proteins, and then used for the growth of new stems and leaves in spring (Babst \& Coleman 2018; Wildhagen et al. 2010). When the deciduous perennial trees overwinter, nitrogen is transported from senescing leaves to perennial tissues for storage (Ryan \& Bormann 1982). For example, before poplar leaf senescence, protein is hydrolyzed and transported to stems and roots in the form of amino acids, which results in approximately $90 \%$ of the nitrogen being removed from the leaves (Chapin \& Kedrowski 1983; Pregitzer et al. 1990). Through longitudinal section observation of Populus stems in winter and summer, it has been found that the phloem parenchyma cells and xylem ray cells contained only a large central vacuole in summer, while the central vacuole in these cells was replaced by many small protein storage vacuoles in winter (Clausen \& Apel 1991; Cleve \& Apel 1993; Cleve et al. 1988; Cooke \& Weih 2005; Sauter et al. 1989; Sauter \& Cleve 1992; Wetzel et al. 1989a). This protein is a kind of vegetative storage protein (VSP) and is a designated bark storage protein (BSP) (Cooke \& Weih 2005). It is an important form of nitrogen storage for perennial woody plants in winter.

Previous studies have shown that the poplar $B S P$ is composed of a multigene family, including three subfamilies: BSP, wound-inducible 4 (WIN4), and poplar nitrogen-inducible 288 (PNI288) (Coleman et al. 1992; Wildhagen et al. 2010). All three subfamily genes can respond to nitrogen induction (Coleman et al. 1994; Lawrence et al. 2001; Lawrence et al. 1997), but only $B S P$ has been found to exhibit consistent seasonal expression changes with the total protein concentration in bark. The expression of $B S P$ was increased in winter, whereas the expression of WIN4 and PNI288 increased only in spring (Wildhagen et al. 2010), and BSP has been reported to respond to short light duration and low temperature induction (Black et al. 2001; Cleve \& Apel 1993; Coleman et al. 1991; Coleman et al. 1993; Lawrence et al. 2001; Wildhagen et al. 2013). Therefore, only $B S P$ is directly related to nitrogen storage during plant dormancy in winter among these three subfamilies.

Jatropha curcas is a perennial woody oil plant of the Euphorbiaceae family. It has received widespread attention because its seed oil is recognized as a promising feedstock for biodiesel production (Divakara et al. 2010; Kamel et al. 2018; Makkar \& Becker 2009; Mazumdar et al. 2018; Mohibbeazam et al. 2005; Pandeya et al. 2012; Pramanik 2003; Vaknin et al. 2018; Yi et al. 2014). Although J. curcas grows in tropical and subtropical regions, it is also a deciduous tree. Adult $J$. curcas begins to defoliate in autumn and stays dormant in winter until the next spring, when it enters the growing season. In this study, to identify J. curcas $B S P$ ( $J c B S P$ ) genes that may be involved in seasonal nitrogen cycling, we examined the expression of $J c B S P$ family members in response to seasonal changes and nitrogen induction and found that the expression of $J C B S P 1$ was positively correlated with the total protein concentration in the stems during seasonal changes and with the exogenous nitrogen application. To further determine the roles of JcBSP1 in plant growth and development, we characterized phenotypic changes in transgenic Arabidopsis thaliana overexpressing $J_{C} B S P 1$ and found that transgenic plants exhibited phenotypes of enlarged rosette leaves, flowers, and seeds. These findings laid the foundation for further research on the function of $B S P$ genes in the plant growth and development.

\section{Materials \& Methods}

\section{Plant materials and nitrogen treatment}

Four-year-old adult $J$. curcas were grown in the experimental field of Xishuangbanna Tropical Botanical Garden $\left(21^{\circ} 54^{\prime} \mathrm{N}, 101^{\circ} 46^{\prime} \mathrm{E} ; 580 \mathrm{~m}\right.$ in altitude) in Yunnan Province. Wild-type Arabidopsis thaliana ecotype Columbia (Col-0) and the transgenic lines were grown in an 
87 environmentally controlled room at $22{ }^{\circ} \mathrm{C}$ under a 16-h light/8-h dark photoperiod. Wild-type $J$. 88 curcas seeds were sown in sand that had been washed several times with distilled water and grown 89 at $30^{\circ} \mathrm{C}$ under a 12 -h light/12-h dark photoperiod. Then, two-month-old $J$. curcas seedlings were

\section{RNA extraction}

The samples for RNA extraction included different tissues (roots, stems, shoot apices, young leaves, mature leaves, male flowers, female flowers, fruits and seeds) of four-year-old adult $J$. curcas, stems collected from October 2019 to August 2020, two-month-old J. curcas seedlings treated with different concentrations of $\mathrm{NH}_{4} \mathrm{NO}_{3}$ solution for $0,2,4,6$, and 8 weeks, and leaves of one-month-old WT and transgenic Arabidopsis. These samples were quickly frozen in liquid nitrogen and stored at $-80^{\circ} \mathrm{C}$. Total RNA was extracted using the silica adsorption method (Ding et al. 2008), and the concentration and purity of RNA were detected by spectrophotometry and agarose gel electrophoresis, respectively.

\section{qRT-PCR analysis}

Reverse transcription of total RNA was performed using the PrimeScript ${ }^{\circledR}$ RT reagent kit with gDNA Eraser (Takara, Dalian, China). qRT-PCR was performed on the Roche 480 real-time PCR detection system using LightCycler ${ }^{\circ} 480$ SYBR Green I Master Mix (Roche Diagnostics, Indianapolis, IN, USA). The qRT-PCR reactions were performed under the following conditions: $5 \mathrm{~min}$ at $95^{\circ} \mathrm{C}$ for the initial denaturation, followed by 42 cycles of $10 \mathrm{~s}$ at $95^{\circ} \mathrm{C}, 20 \mathrm{~s}$ at $57^{\circ} \mathrm{C}$, and $20 \mathrm{~s}$ at $72{ }^{\circ} \mathrm{C}$ for the PCR amplification, and 1 cycle of $30 \mathrm{~s}$ at $95^{\circ} \mathrm{C}, 30 \mathrm{~s}$ at $65^{\circ} \mathrm{C}$ and 0.06 ${ }^{\circ} \mathrm{C} / \mathrm{s}$ heating up to $95{ }^{\circ} \mathrm{C}$ for the melting curve. Data was analyzed using the $2^{-\Delta \Delta \mathrm{CT}}$ method as described by Livak \& Schmittgen (2001). All expression data obtained in the qRT-PCR assay were normalized to the expression of JcActin1 (Zhang et al. 2013) and AtActin2. The primers used for qRT-PCR are listed in Table S1. 
133

134

135

136

137

138

139

140

141

142

143

144

145

146

147

148

149

150

151

152

153

154

155

156

157

158

159

160

161

162

163

164

165

166

167

168

169

170

171

172

173

174

175

176

177

178

\section{Protein extraction}

Stem samples of four-year-old adult $J$. curcas collected from October 2019 to August 2020 were also used for total protein extraction. The bark + phloem and xylem + pith dissected from stems were ground into powder mixtures. Fifty milligrams of powder were homogenized in $300 \mu 1$ of protein extract buffer (50 mM Tris-HCl pH 7.4, $150 \mathrm{mM} \mathrm{NaCl}, 1 \mathrm{mM}$ EDTA, 0.1\% Triton X-100, $10 \%$ glycerol). The mixture was incubated at $4{ }^{\circ} \mathrm{C}$ for $30 \mathrm{~min}$ and then centrifuged at $12000 \mathrm{rpm}$ for $15 \mathrm{~min}$ at room temperature. The supernatant was collected and analyzed by a Bradford protein assay kit (BL524A, GUANGKE Technology Company, Kunming).

\section{Correlation analysis}

Correlation analysis between the total protein concentration and $J c B S P 1$ expression was performed by the method of Spearman's rank correlation using $\mathrm{R}$ package ggpubr (version 0.4.0, https://cran.r-project.org/).

\section{Construction of the JcBSP1 overexpression vector and Arabidopsis transformation}

The primers XD423 (CGAGCTCATGGCTATGGCGACGGTGAT) and XD424 (CGGATCCTCACTCTTCATCATAACGGA) carrying SacI and BamHI restriction sites, respectively, were used to clone the full-length $J_{C B S P 1}$ CDS. Then, the PCR product was cloned into the pGEM-T Easy vector (Promega, Madison, WI, USA). To generate the 35S:JcBSP1 overexpression vector, $S a c \mathrm{I}$ and $B a m \mathrm{HI}$ were used to digest the plant transformation vector pOCA30 (Chen \& Chen 2002) and the pGEM-T Easy vector containing the JcBSPI sequence, respectively, and then, the resulting fragments were ligated by using T4 DNA Ligase (Promega). The generated 35S:JCBSP1 plasmid was transferred to Agrobacterium tumefaciens EHA105. Transformation of Arabidopsis was performed using the floral dip method (Clough \& Bent 1998).

\section{Results}

\section{Identification of the members of the JcBSP gene family}

We found six members of the $J c B S P$ gene family in $J$. curcas from the NCBI database using BLAST and designated them as $J_{c B S P 1,} J_{c B S P}$, $J_{c B S P}$, $J_{c B S P}$, $J_{c B S P 5}$, and $J_{c B S P 6}$ (Table 1). All the $J c B S P$ gene family members contain a conserved domain, purine nucleoside phosphorylase_uridine phosphorylase_1(PNP_UDP_1), which is a signature of the phosphorylase superfamily (Figure 1).

To investigate the evolutionary relationships among BSP homologous genes, we performed phylogenetic analysis of genes from $J$. curcas and other species. The phylogenetic tree showed that JcBSP1, JcBSP5, and JcBSP6 were closely related to the BSP homologues from Euphorbiaceous species, and JcBSP2, JcBSP3, and JcBSP4 were closely related to the BSP homologues from poplar (Figure 2).

\section{The expression patterns of JcBSPs in J. curcas}

To analyze the expression patterns of $J c B S P$ family members, we used qRT-PCR to detect the expression levels of $J_{C B S P}$ in roots, stems, shoot apices, young leaves, mature leaves, male flowers, female flowers, fruits, and seeds of adult J. curcas. The results showed that $J C B S P 1$ and $J C B S P 2$ exhibited similar expression patterns, in which both were highly expressed in shoot apices, stems, young leaves and female flowers; JcBSP3 was mainly expressed in roots, stems, shoot apices, male flowers and fruits; the expression of $J_{C B S P 4}$ was concentrated in reproductive tissues, with the highest expression level in female flowers; the expression of $J c B S P 5$ was concentrated in 
179

180

181

182

183

184

185

186

187

188

189

190

191

192

193

194

195

196

197

198

199

200

201

202

203

204

205

206

207

208

209

210

211

212

213

214

215

216

217

218

219

220

221

222

223

vegetative tissues, with the highest expression level in stems; and JcBSP6 was remarkably expressed in male flowers (Figure 3). Based on these results, we hypothesized that $J c B S P$ s could play important roles in the growth and development of various organs, except seeds, in which all the members were barely expressed. This finding also indicates that JcBSPs may be vegetative storage proteins rather than seed storage proteins.

\section{Seasonal changes in total protein concentrations and $J c B S P$ expression in the stems of $J$. curcas}

In perennial deciduous trees, most nitrogen resources in senescing leaves are transported to perennial tissues (bark and wood), and stored as proteins during autumn and winter; the next spring, these proteins are hydrolyzed to amino acids, which are transported from perennial tissues to growing tissues (Chapin \& Kedrowski 1983; Cooke \& Weih 2005; Sauter et al. 1989). Therefore, we investigated whether the total protein concentration in J. curcas stems was relevant to seasons.

From October 2019 to August 2020, we sampled the stems of adult $J$. curcas in two parts (bark + phloem and xylem + pith), as shown in Figure $4 \mathrm{~A}$, and examined the total protein concentrations of the samples. The results showed that the total protein concentrations in the bark + phloem and xylem + pith were approximately $10.5 \mathrm{mg} / \mathrm{g} \mathrm{FW}$ in October; then, J. curcas entered the dormant stage in December, and the total protein concentration reached a peak in the bark + phloem $(12.3 \mathrm{mg} / \mathrm{g} \mathrm{FW})$ and xylem + pith $(16.4 \mathrm{mg} / \mathrm{g} \mathrm{FW})$. When $J$. curcas began to enter the growing season in March, the total protein concentration decreased sharply to $7 \mathrm{mg} / \mathrm{g} F W$ in the bark + phloem, which further decreased to $5.5 \mathrm{mg} / \mathrm{g} \mathrm{FW}$ in August. The total protein concentration in the xylem + pith showed a similar trend (Figure 4B). The total protein concentration in the $J$. curcas stem exhibited a seasonal change, which accumulated in autumn and winter and decreased in spring and summer. This result indicates that the total protein in the stems is a form of nitrogen storage during the overwintering period of J. curcas, and this protein is reallocated during the growing seasons.

Based on the above results, we examined the seasonal course of $J c B S P$ expression in the same samples mentioned above (Figure 4A) to investigate whether the expression of $J C B S P$ s shows the same seasonal changes as the total protein concentration. The results showed that the expression of $J c B S P$ family members in stems exhibited different patterns over the seasonal course (Figure 5). From autumn to winter, the expression of $J c B S P 1$ in the two parts of the stems increased rapidly, with a higher level in xylem + pith, and then decreased sharply in spring and remained low until August. The seasonal changes in $J_{C B S P} 1$ expression in the two parts of the stem were entirely consistent with those of the total protein concentration. However, the seasonal expression patterns of $J_{C B S P 2}, J_{c B S P 4}$ and $J_{C B S P 5}$ in stems were inconsistent with those of the total protein concentration. In addition, only in the xylem + pith did the expression of JcBSP3 and JcBSP6 show the same seasonal changes as that of the total protein concentration, but their expression levels were much lower than that of $J c B S P 1$. Therefore, we analyzed the correlation between seasonal changes in the total protein concentration and $J_{C B S P} 1$ expression. It turned out that there were significant correlations between them in the bark + phloem $(r=0.63, P<0.01)$ and the xylem + pith $(r=0.67, P<0.01)$ (Figure 6$)$. These results suggest that $J c B S P 1$ might play an important role in seasonal nitrogen cycling.

\section{$J c B S P$ expression in response to nitrogen}

Peer) reviewing PDF | (2021:11:67448:1:0:NEW 29 Dec 2021) 
To further verify the correlation between $J c B S P$ s and seasonal nitrogen cycling, we investigated the response of these genes to nitrogen induction. We applied a 0,5 , and $50 \mathrm{mM}$ $\mathrm{NH}_{4} \mathrm{NO}_{3}$ solution to two-month-old $J$. curcas seedlings. After 8 weeks of treatment, we found that the group treated with the $5 \mathrm{mM} \mathrm{NH}_{4} \mathrm{NO}_{3}$ solution grew better than the other two groups (Figure 7A). This result indicated that nitrogen supply in a certain concentration range could effectively promote the growth of $J$. curcas.

We collected the leaves of $J$. curcas seedlings treated with different concentrations of $\mathrm{NH}_{4} \mathrm{NO}_{3}$ for $0,2,4,6$, and 8 weeks to detect changes in $J c B S P$ family member expression. The results showed that the expression of $J C B S P 1$ increased obviously along with the increased $\mathrm{NH}_{4} \mathrm{NO}_{3}$ concentration and application duration; JcBSP2 expression increased remarkably with the $5 \mathrm{mM} \mathrm{NH}_{4} \mathrm{NO}_{3}$ treatment for 2-8 weeks and with $50 \mathrm{mM} \mathrm{NH}_{4} \mathrm{NO}_{3}$ treatments for 8 weeks; $J_{C B S P 4}$ expression was induced obviously with only the $50 \mathrm{mM} \mathrm{NH}_{4} \mathrm{NO}_{3}$ treatment for 4 weeks; however, the expression of $J c B S P 3, J c B S P 5$ and $J c B S P 6$ was not induced by $\mathrm{NH}_{4} \mathrm{NO}_{3}$ treatment (Figure 7B). The results indicated that $J_{C B S P 1}$ and $J_{C B S P 2}$ expression is responsive to nitrogen induction. In particular, JcBSP1 expression was positively correlated with the nitrogen concentration and application duration. Combined with the seasonal changes in $J C B S P 1$ expression in stems, we further concluded that JcBSP1 is a form of nitrogen storage in the seasonal nitrogen cycle in $J$. curcas.

\section{Overexpression of $J$. curcas $J c B S P 1$ in Arabidopsis led to enlarged rosette leaves, flowers, and seeds}

Next, we investigated the function of $J C B S P 1$ in plant growth and development in transgenic Arabidopsis. Twenty-two independent 35S:JcBSP1 transgenic Arabidopsis lines were generated (Figure 8A). JcBSP1 expression in seven transgenic lines showing similar phenotypes was analyzed, and most of transgenic lines yielded abundant transgene expression (Figure S1). We investigated in further detail the phenotypes of two independent transgenic lines, L4 and L10, which exhibited high and intermediate expression levels of $J_{C B S P 1}$, respectively (Figure 8B).

During plant growth and development, we found that 35S:JcBSP1 transgenic Arabidopsis produced larger rosette leaves and flowers than the wild-type (WT) plants (Figure 8C and 8D). As shown in Figure 8E and 8F, the rosette leaf lengths and widths were all significantly increased in transgenic lines. And larger seeds and significantly increased hundred-seed weights were found in transgenic plants (Figure 9A and 9B). Consequently, the seed yields in transgenic lines were significantly higher than that of the WT (Figure 9C). These results indicated that JcBSP1 was able to affect plant growth and development.

\section{Discussion}

BSP, a kind of VSP, is a main nutrient storage protein in perennial woody plants and a form of nitrogen storage in vegetative tissues (Cooke \& Weih 2005; Staswick 1994). It is different from seed storage protein, which accumulates during seed maturation and provides a nitrogen source for embryo development (Autran et al. 2001; Gacek et al. 2018; Kawakatsu et al. 2010). In Populus, BSP has been found to be highly expressed in the bark, dormant cambium and bud (Coleman et al. 1994; Cooke \& Weih 2005), and the $b s p A$ promoter has been shown to be predominantly active in bark (Zhu \& Coleman 2001). In this study, we identified six members of the $J c B S P$ gene family in $J$. curcas, and none of them were expressed in seeds (Figure 3), indicating that JcBSP might be a nutrient storage protein rather than seed storage protein. In addition, JcBSP1, $J C B S P 2$ and $J C B S P 4$ were highly expressed in female flowers, and $J c B S P 3$ and $J c B S P 6$ were 
270 relatively highly expressed in male flowers, suggesting that they may be involved in the

271

272

273

274

275

276

277

278

279

280

281

282

283

284

285

286

287

288

289

290

291

292

293

294

295

296

297

298

299

300

301

302

303

304

305

306

307

308

309

310

311

312

313

314

315 development of female and male flowers, respectively.

In perennial woody plants, BSP plays an important role in seasonal nitrogen cycling (Wetzel et al. 1989b; Wetzel \& Greenwood 1989; Wildhagen et al. 2010). During autumn and winter, nitrogen-rich amino acids are transported from senescing leaves to perennial tissues and subsequently used to synthesize proteins for nitrogen storage (Geßler et al. 2004; Hörtensteiner \& Feller 2002). BSP is the main form of nitrogen storage in trees during the dormant period, which accumulates in autumn and winter (Cooke \& Weih 2005; Wetzel et al. 1989b). In this study, we found that the seasonal changes in $J_{C B S P} 1$ expression in stems were consistent with those of the total protein concentration, as both increased in autumn and winter and then decreased in spring and summer (Figure 4B and Figure 5). And there is a significant correlation between seasonal changes in the total protein concentration and JcBSPl expression (Figure 6), suggesting that JcBSP1 might be the main protein stored in the stem of $J$. curcas during overwintering. Moreover, the expression of $J c B S P 1$ was positively correlated with the nitrogen concentration and application duration (Figure 7B). Therefore, we hypothesized that JcBSP1 might play an important role in the seasonal nitrogen cycle of $J$. curcas, acting as a form of nitrogen storage in the stems during overwintering. In addition, this study was conducted in the Xishuangbanna Tropical Botanical Garden, Chinese Academy of Sciences, which is located in a tropical region of China. According to rainfall, there are two seasons, a rainy season from May to October and a dry season from November to April of the following year, in Xishuangbanna area. The dry season is further divided into the foggy-cool season from November to February of the following year and the dry-hot season from March to April. Although the foggy-cool season has little precipitation, there is a large amount of dense fog from night to noon, which has a certain compensation effect on the water demand of plants in dry season; the dry-hot season has a dry climate, low precipitation and large daily temperature differences (Zhao et al. 2009). As shown in Figure 4B and Figure 5, both of the total protein concentration and $J_{C B S P} 1$ expression in the stems were decreased to a very low level at the beginning of the dry-hot season. Hence, further studies are required to link the seasonal changes in total protein concentration and JcBSP1 expression to possible drought-related protein mobilization.

It is well known that nitrogen is an important nutrient for plant growth and development. Lemaitre et al. (2008) showed that when Arabidopsis grew under low nitrogen conditions, rosette biomass and seed yield were limited. Storage proteins are considered as nitrogen source that are utilized for plant growth (Sözen 2004; Titus \& Kang 1982). In this study, we found that overexpression of $J c B S P 1$ could promote the growth and development of rosette leaves, flowers, and seeds in transgenic Arabidopsis (Figure 8 and 9). This finding further indicates the JcBSP1 might be a form of nitrogen storage in plants, serving as a nutrient provider. Similarly, overexpression of a storage protein gene $A m A 1$ in potato could increase the growth and production of tubers (Chakraborty et al. 2000). By analyzing cell architectures, the cell areas in cortex, perimedullary and pith regions of the tuber were found to be increased, which indicated the AmA1 storage protein in potato tuber was correlated with cell growth (Agrawal et al. 2013). In cabbage, when the nitrogen supply can't meet the need of plant growth, the leaf cells became smaller while the number of cell layers remained unchanged (Kano et al. 2007). It turns out that both endogenous and exogenous nitrogen sources could affect cell growth. Accordingly, overexpression of JcBSP1 in transgenic Arabidopsis may also promote the cell growth, resulting in enhanced plant growth and production. Furthermore, it is worthy to mention here that although the expression level of $J C B S P 1$ in the transgenic line L4 was higher than that in L10 (Figure 8B), the leaves and seeds in

Peer) reviewing PDF | (2021:11:67448:1:0:NEW 29 Dec 2021) 
316 L4 were relatively smaller than those in L10 (Figure 8C, E, F; Figure 9). We hypothesized that 317 this phenotype might be caused by the excessively high $J_{c} B S P 1$ transgene expression, which might 318 lead to excess JcBSP1 protein storage and subsequently excess nitrogen accumulation in L4 plants. 319 Previous study showed that under the excess nitrogen conditions, both cell number and size were 320 found to be reduced in leaves (MacAdam et al. 1988). In addition, about half of the Rubisco are

321

322

323

324

325

326

327

328

329

330

331

332

333

334

335

336

337

338

339

340

341

342

343

344 inactive or only half of the catalytic sites are functional, which certainly leads to a decrease in photosynthetic efficiency and therefore a retardation in plant growth (Chapin et al. 1990; Cheng \& Fuchigami 2000; Millard 1988). As shown in Figure 7A, the excessive nitrogen supply does have a certain negative impact on $J$. curcas growth. Consistently, Barbosa et al. (2010) also found that when the adding nitrogen concentration was below $40 \mathrm{mM}$, it stimulated Arabidopsis root growth, while the concentration was higher than $40 \mathrm{mM}$, root elongation was inhibited.

In addition, VSPs may also play a role in plant defense. In Arabidopsis, AtVSP1 and AtVSP2 have been shown to enhance plant resistance to diseases and insects (Berger et al. 2002; Ellis \& Turner 2001; Liu et al. 2005). Furthermore, AtVSP1 and AtVSP2 have been found to be highly expressed in flowers (Utsugi et al. 1998), which implies a mechanism used by Arabidopsis to protect reproductive structures (Liu et al. 2005). Interestingly, most $J c B S P$ s were also highly expressed in female or male flowers (Figure 3). Thus, in addition to being a provider of nitrogen resources, $J c B S P$ s may also play other roles in plant growth and development, which requires further study.

\section{Conclusions}

In this study, six members of the $J c B S P$ gene family were identified in $J$. curcas, which were expressed in various tissues, except seeds. Among these members, only the expression of $J c B S P 1$ was positively correlated with the total protein concentration in the stems during seasonal changes and with the exogenous nitrogen application. We thus supposed that JcBSP1 could play an important role in seasonal nitrogen cycling as a form of nitrogen storage. By the function analysis of $J c B S P 1$ in transgenic Arabidopsis, we found that $J c B S P 1$ was able to enhance the plant growth and production. This suggests that $J C B S P 1$ could be useful in crop breeding.

\section{Acknowledgements}

The authors gratefully acknowledge the Central Laboratory of the Xishuangbanna Tropical Botanical Garden for providing the research facilities.

\section{References}

Agrawal L, Narula K, Basu S, Shekhar S, Ghosh S, Datta A, Chakraborty N, and Chakraborty S. 2013. Comparative proteomics reveals a role for seed storage protein AmA1 in cellular growth, development, and nutrient accumulation. Journal of Proteome Research 12:4904-4930. 10.1021/pr4007987

Autran JC, Halford NG, and Shewry PR. 2001. The biochemistry and molecular biology of seed storage proteins. Springer Berlin Heidelberg:295-341. 10.1007/978-3-662-04064-5_12

Babst BA, and Coleman GD. 2018. Seasonal nitrogen cycling in temperate trees: Transport and regulatory mechanisms are key missing links. Plant Science 270:268-277. 10.1016/j.plantsci.2018.02.021 
359

360

361

362

363

364

365

366

367

368

369

370

371

372

373

374

375

376

377

378

379

380

381

382

383

384

385

386

387

388

389

390

391

392

393

394

395

396

397

398

399

400

401

402

403

404

405

406

407

Barbosa JM, Singh NK, Cherry JH, and Locy RD. 2010. Nitrate uptake and utilization is modulated by exogenous gamma-aminobutyric acid in Arabidopsis thaliana seedlings. Plant Physiology and Biochemistry 48:443-450. 10.1016/j.plaphy.2010.01.020

Berger S, Mitchell-Oldsb T, and Stotz HU. 2002. Local and differential control of vegetative storage protein expression in response to herbivore damage in Arabidopsis thaliana. Physiologia Plantarum 114:85-91. 10.1046/j.0031-9317.2001.1140112.x

Black BL, Parmentier-Line CM, Fuchigami LH, and Coleman GD. 2001. Ecotypic and genetic variation in poplar bark storage protein gene expression and accumulation. Tree Physiology 21:1289-1297. 10.1093/treephys/21.17.1289

Chakraborty S, Chakraborty N, and Datta A. 2000. Increased nutritive value of transgenic potato by expressing a nonallergenic seed albumin gene from Amaranthus hypochondriacus. PNAS 97:3724-3729 10.1073/pnas.050012697

Chapin FS, and Kedrowski RA. 1983. Seasonal changes in nitrogen and phosphorus fractions and autumn retranslocation in evergreen and deciduous taiga trees. Ecology 64:376391. $10.2307 / 1937083$

Chapin FS, Schulze ED, and Mooney HA. 1990. The ecology and economics of storage in plants. Annual Review of Ecology and Systematics 21:423-447. 10.1146/annurev.ecolsys.21.1.423

Chen $\mathrm{CH}$, and Chen ZX. 2002. Potentiation of developmentally regulated plant defense response by AtWRKY18, a pathogen-induced Arabidopsis transcription factor. Plant Physiology 129:706-716. 10.1104/pp.001057

Cheng LL, and Fuchigami LH. 2000. Rubisco activation state decreases with increasing nitrogen content in apple leaves. Journal of Experimental Botany 51:1687-1694. 10.1093/jexbot/51.352.1949-a

Clausen S, and Apel K. 1991. Seasonal changes in the concentration of the major storage protein and its mRNA in xylem ray cells of poplar trees. Plant Molecular Biology 17:669678. 10.1007/BF00037052

Cleve BV, and Apel K. 1993. Induction by nitrogen and low temperature of storage-protein synthesis in poplar trees exposed to long days. Planta 189:157-160. 10.1007/BF00201357

Cleve BV, Clausen S, and Sauter JJ. 1988. Immunochemical localization of a storage protein in poplar wood. Plant Physiology 133:371-374. 10.1016/S0176-1617(88)80219-0

Clough SJ, and Bent AF. 1998. Floral dip: a simplified method for Agrobacterium-mediated transformation of Arabidopsis thaliana. The Plant Journal 16:735-743. 10.1046/j.1365313x.1998.00343.x

Coleman GD, Baíiados MP, and Chen THH. 1994. Poplar bark storage protein and a related wound-induced gene are differentially induced by nitrogen. Plant Physiology 106:211215. 10.1104/pp.106.1.211

Coleman GD, Chen THH, Ernst SG, and Fuchigami L. 1991. Photoperiod control of poplar bark storage protein accumulation. Plant Physiology 96:686-692. 10.1104/pp.96.3.686

Coleman GD, Chen THH, and Fuchigami LH. 1992. Complementary DNA cloning of poplar bark storage protein and control of its expression by photoperiod. Plant Physiology 98:687693. 10.1104/pp.98.2.687

Coleman GD, Englert JM, Chen THH, and Fuchigami LH. 1993. Physiological and environmental requirements for poplar (Populus deltoides) bark storage protein degradation. Plant Physiology 102:53-59. 10.1104/pp.102.1.53

Cooke JEK, and Weih M. 2005. Nitrogen storage and seasonal nitrogen cycling in Populus : bridging molecular physiology and ecophysiology. New Phytologist 167:19-30. 10.1111/j.1469-8137.2005.01451.x

Peer) reviewing PDF | (2021:11:67448:1:0:NEW 29 Dec 2021) 
408

409

410

411

412

413

414

415

416

417

418

419

420

421

422

423

424

425

426

427

428

429

430

431

432

433

434

435

436

437

438

439

440

441

442

443

444

445

446

447

448

449

450

451

452

453

454

455

456

Ding LW, Sun QY, Wang ZY, Sun YB, and Xu ZF. 2008. Using silica particles to isolate total RNA from plant tissues recalcitrant to extraction in guanidine thiocyanate. Analytical Biochemistry 374:426-428. 10.1016/j.ab.2007.11.030

Divakara BN, Upadhyaya HD, Wani SP, and Gowda CLL. 2010. Biology and genetic improvement of Jatropha curcas L.: A review. Applied Energy 87:732-742. 10.1016/j.apenergy.2009.07.013

Ellis C, and Turner JG. 2001. The Arabidopsis mutant cev1 has constitutively active jasmonate and ethylene signal pathways and enhanced resistance to pathogens. The Plant Cell 13:1025-1033. 10.2307/3871361

Gacek K, Bartkowiak-Broda I, and Batley J. 2018. Genetic and molecular regulation of seed storage proteins (SSPs) to improve protein nutritional value of oilseed rape (Brassica napus L.) seeds. Frontiers in Plant Science 9:890. 10.3389/fpls.2018.00890

Geßler A, Kopriva S, and Rennenberg H. 2004. Regulation of nitrate uptake at the whole-tree level: interaction between nitrogen compounds, cytokinins and carbon metabolism. Tree Physiology 24:1313-1321. 10.1093/treephys/24.12.1313

Hörtensteiner S, and Feller U. 2002. Nitrogen metabolism and remobilization during senescence. Journal of Experimental Botany 53:927-937. 10.1093/jexbot/53.370.927

Kamel DA, Farag HA, Amin NK, Zatout AA, and Ali RM. 2018. Smart utilization of jatropha (Jatropha curcas Linnaeus) seeds for biodiesel production: Optimization and mechanism. Industrial Crops and Products 111:407-413. 10.1016/j.indcrop.2017.10.029

Kano Y, Nakagawa H, Sekine M, Goto H, and Sugiura A. 2007. Effect of nitrogen fertilizer on cell size and sugar accumulation in the leaves of cabbage (Brassica oleracea L.). HortScience 42:1490-1492. 10.1590/S0102-05362007000400022

Kawakatsu T, Hirose S, Yasuda H, and Takaiwa F. 2010. Reducing rice seed storage protein accumulation leads to changes in nutrient quality and storage organelle formation. Plant Physiology 154:1842-1854. 10.1104/pp.110.164343

Lawrence SD, Cooke JEK, Greenwood JS, Korhnak TE, and Davis JM. 2001. Vegetative storage protein expression during terminal bud formation in poplar. Canadian Journal of Forest Research 31:1098-1103. 10.1139/cjfr-31-6-1098

Lawrence SD, Greenwood JS, Korhnak TE, and Davis JM. 1997. A vegetative storage protein homolog is expressed in the growing shoot apex of hybrid poplar. Planta 203:237-244. $10.1007 / \mathrm{s} 004250050187$

Lemaitre T, Gaufichon L, Boutet-Mercey S, Christ A, and Masclaux-Daubresse C. 2008. Enzymatic and metabolic diagnostic of nitrogen deficiency in Arabidopsis thaliana Wassileskija accession. Plant \& Cell Physiology 49:1056-1065. 10.1093/pcp/pcn081

Liu YL, Ahn JE, Datta S, Salzman RA, Moon J, Huyghues-Despointes B, Pittendrigh B, Murdock LL, Koiwa H, and Zhu-Salzman K. 2005. Arabidopsis vegetative storage protein is an anti-insect acid phosphatase. Plant Physiology 139:1545-1556. 10.1104/pp.105.066837

Livak KJ, and Schmittgen TD. 2001. Analysis of relative gene expression data using real-time quantitative PCR and the 2(-Delta Delta C(T)) Method. Methods 25:402-408. 10.1006/meth.2001.1262

MacAdam JW, Volenec JJ, and Nelson CJ. 1988. Effects of nitrogen on mesophyll cell division and epidermal cell elongation in tall fescue leaf blades. Plant Physiology 89:549-556. 10.1104/pp.89.2.549

Makkar HPS, and Becker K. 2009. Jatropha curcas, a promising crop for the generation of biodiesel and value-added coproducts. European Journal of Lipid Science and Technology 111:773-787. 10.1002/ejlt.200800244

May JD, and Killingbeck KT. 1992. Effects of preventing nutrient resorption on plant fitness and foliar nutrient dynamics. Ecology 73:1868-1878. 10.2307/1940038

PeerJ reviewing PDF | (2021:11:67448:1:0:NEW 29 Dec 2021) 
457

458

459

460

461

462

463

464

465

466

467

468

469

470

471

472

473

474

475

476

477

478

479

480

481

482

483

484

485

486

487

488

489

490

491

492

493

494

495

496

497

498

499

500

501

502

503

504

505

506

Mazumdar P, Singh P, Babu S, Siva R, and Harikrishna JA. 2018. An update on biological advancement of Jatropha curcas L.: New insight and challenges. Renewable and Sustainable Energy Reviews 91:903-917. 10.1016/j.rser.2018.04.082

Millard P. 1988. The accumulation and storage of nitrogen by herbaceous plants. Plant, Cell and Environment 11:1-8. 10.1111/j.1365-3040.1988.tb01769.x

Mohibbeazam M, Waris A, and Nahar N. 2005. Prospects and potential of fatty acid methyl esters of some non-traditional seed oils for use as biodiesel in India. Biomass and Bioenergy 29:293-302. 10.1016/j.biombioe.2005.05.001

Pandeya VC, Singh K, Singh JS, Kumar A, Singh B, and Singh RP. 2012. Jatropha curcas: A potential biofuel plant for sustainable environmental development. Renewable and Sustainable Energy Reviews 16:2870-2883. 10.1016/j.rser.2012.02.004

Pramanik K. 2003. Properties and use of jatropha curcas oil and diesel fuel blends in compression ignition engine. Renewable Energy 28:239-248. 10.1016/S09601481(02)00027-7

Pregitzer KS, Dickmann DI, Hendrick R, and Nguyen PV. 1990. Whole-tree carbon and nitrogen partitioning in young hybrid poplars. Tree Physiology 7:79-93. 10.1093/treephys/7.1-2-34.79

Ryan DF, and Bormann FH. 1982. Nutrient resorption in northern hardwood forests. BioScience 32:29-32. 10.2307/1308751

Sauter BJJ, Cleve BV, and Wellenkamp S. 1989. Ultrastructural and biochemical results on the localization and distribution of storage proteins in a poplar tree and in twigs of other tree species. Holzforschung 43:1-6. 10.1515/hfsg.1989.43.1.1

Sauter JJ, and Cleve BV. 1992. Seasonal variation of amino acids in the xylem sap of "Populus $\mathrm{X}$ canadensis" and its relation to protein body mobilization. Tree 7:26-32. $10.1007 / B F 00225228$

Sözen E. 2004. Vegetative storage proteins in plants. Anadolu University Journal of Science and Technology 5:1-7.

Staswick PE. 1994. Storage proteins of vegetative plant tissues. Annual Review of Plant Physiology and Plant Molecular Biology 45:303-322. 10.1146/annurev.pp.45.060194.001511

Titus JS, and Kang SM. 1982. Nitrogen metabolism, translocation, and recycling in apple trees. Horticultural Reviews 4:204-246. 10.1002/9781118060773.ch7

Utsugi S, Sakamoto W, Murata M, and Motoyoshi F. 1998. Arabidopsis thaliana vegetative storage protein (VSP) genes: gene organization and tissue-specific expression. Plant Molecular Biology 38:565-576. 10.1023/A:1006072014605

Vaknin Y, Yermiyahu U, Bar-Tal A, and Samocha Y. 2018. Global maximization ofJatrophaoil production under semi-arid conditions by balancing vegetative growth with reproductive capacity. GCB Bioenergy 10:382-392. 10.1111/gcbb.12497

Wetzel S, Demmers C, and Greenwood JS. 1989a. Spherical organelles, analogous to seed protein bodies, fluctuate seasonally in parenchymatous cells of hardwoods. Canadian Journal of Botany 67:3439-3445. 10.1139/b89-420

Wetzel S, Demmers C, and Greenwood JS. 1989b. Seasonally fluctuating bark proteins are a potential form of nitrogen storage in three temperate hardwoods. Planta 178:275-281. 10.1007/BF00391854

Wetzel S, and Greenwood JS. 1989. Proteins as a potential nitrogen storage compound in bark and leaves of several softwoods. Trees 3:149-153. 10.1007/BF00226650

Wildhagen H, Bilela S, and Rennenberg H. 2013. Low temperatures counteract short-day induced nitrogen storage, but not accumulation of bark storage protein transcripts in bark of grey poplar (Populus $x$ canescens) trees. Plant Biology 15:44-56. 10.1111/j.14388677.2012.00687.x

Peer] reviewing PDF | (2021:11:67448:1:0:NEW 29 Dec 2021) 
507

508

509

510

511

512

513

514

515

516

517

518

519

520

521

522

523
Wildhagen H, Dürr J, Ehlting B, and Rennenberg H. 2010. Seasonal nitrogen cycling in the bark of field-grown grey poplar is correlated with meteorological factors and gene expression of bark storage proteins. Tree Physiology 30:1096-1110. 10.1093/treephys/tpq018

Yi CX, Reddy C, Varghese K, Bui TNH, Zhang SL, Kallath M, Kunjachen B, Ramachandran S, and Hong Y. 2014. A new Jatropha curcas variety (JO S2) with improved seed productivity. Sustainability 6:4355-4368. 10.3390/su6074355

Zhang L, He LL, Fu QT, and Xu ZF. 2013. Selection of reliable reference genes for gene expression studies in the biofuel plant Jatropha curcas using real-time quantitative PCR. International Journal of Molecular Sciences 14:24338-24354. 10.3390/ijms141224338

Zhao JB, Zhang YP, Song FQ, Xu ZF, and Xiao YL. 2009. A comparison of the phenological characteristics of introduced plant species in the Xishuangbanna Tropical Botanical Garden. Chinese Bulletin of Botany 44:464-472. 10.3969/j.issn.1674-3466.2009.04.008

Zhu BL, and Coleman GD. 2001. The poplar bark storage protein gene (Bspa) promoter is responsive to photoperiod and nitrogen in transgenic poplar and active in floral tissues, immature seeds and germinating seeds of transgenic tobacco. Plant Molecular Biology 46:383-394. 10.1023/A:1010600504740 


\section{Table $\mathbf{1}$ (on next page)}

Sequence information for members of the JcBSP family in J. curcas. 
Table 1. Sequence information for members of the $J c B S P$ family in $J$. curcas.

\begin{tabular}{ccccc}
\hline $\begin{array}{c}\text { Gene } \\
\text { name }\end{array}$ & $\begin{array}{c}\text { GenBank } \\
\text { accession number }\end{array}$ & $\begin{array}{c}\text { cDNA } \\
\text { (bp) }\end{array}$ & $\begin{array}{c}\text { CDS } \\
\text { (bp) }\end{array}$ & $\begin{array}{c}\text { Number of } \\
\text { amino acids (aa) }\end{array}$ \\
\hline$J_{C B S P 1}$ & XM_012218517 & 1248 & 972 & 323 \\
$J_{C B S P 2}$ & XM_012214829 & 1144 & 1017 & 338 \\
$J_{C B S P 3}$ & XM_012218526 & 959 & 843 & 280 \\
$J_{C}$ BSP4 & XM_012218520 & 1038 & 702 & 233 \\
$J_{C}$ BSP5 & XM_012222025 & 1274 & 1062 & 353 \\
$J_{C}$ BSP6 & XM_012222124 & 1174 & 1041 & 346 \\
\hline
\end{tabular}




\section{Figure 1}

Protein sequence alignment of JCBSP family members of $J$. curcas.

Identically conserved amino acid sequences are shown with a dark blue background, and partially conserved amino acid sequences are shown with grey and brown backgrounds; the conserved PNP_UDP_1 domain of JCBSP is indicated with overlining.

JCBSP1 JCBSP2

JCBSP3

JCBSP4

JCBSP5

JCBSP6

JCBSP1

JCBSP2

JCBSP3

JCBSP4

JCBSP5

JCBSP6

JCBSP1

JCBSP2

JCBSP3

JCBSP4

JCBSP5

JCBSP6

JCBSP1

JCBSP2

JCBSP3

JCBSP 4

JCBSP5

JCBSP 6

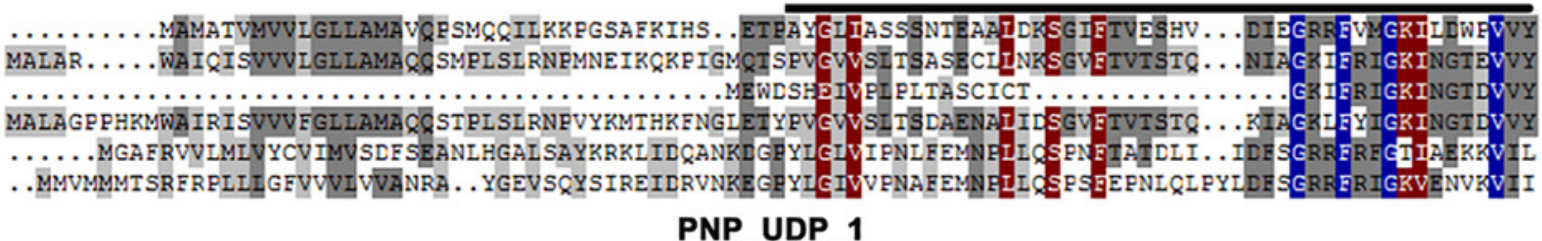

PNP_UDP_1
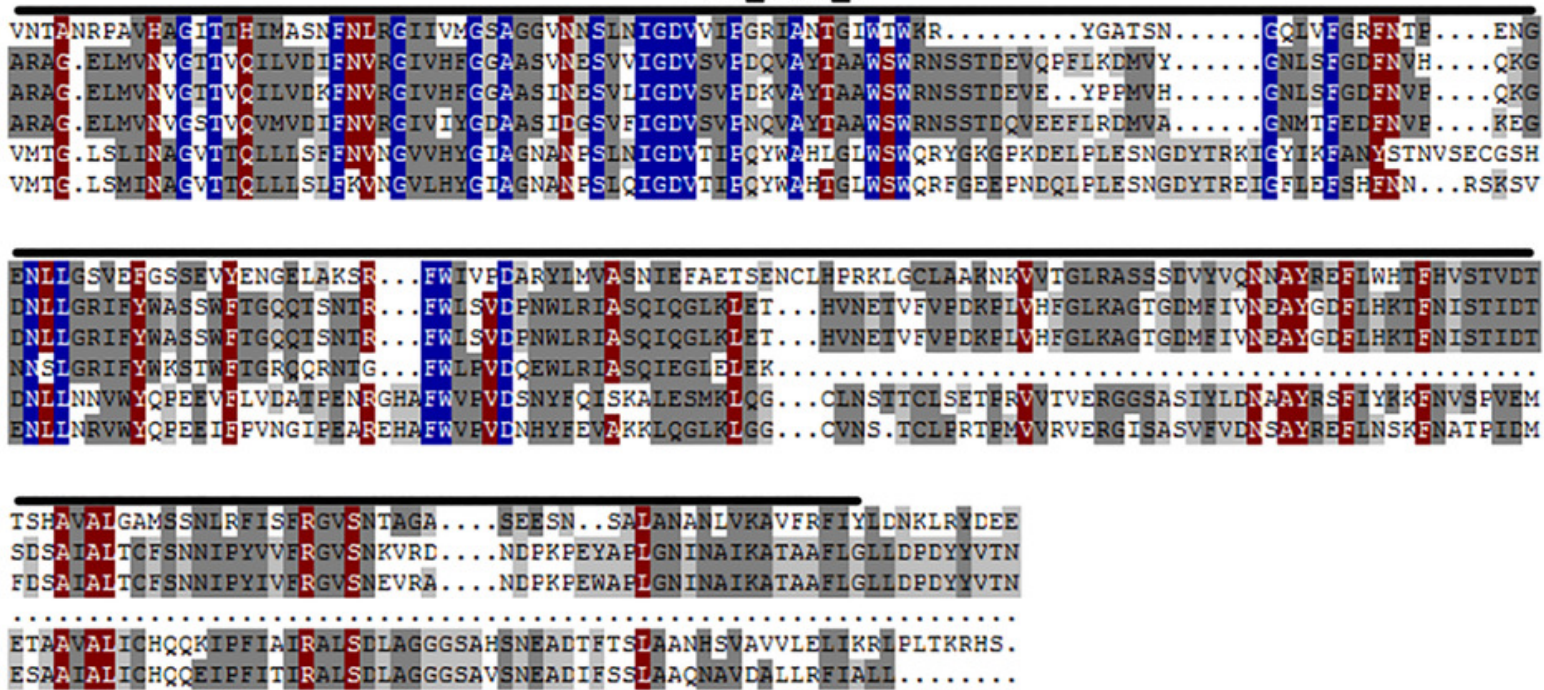


\section{Figure 2}

Phylogenetic tree analysis of BSP homologues.

The homologues compared with J. curcas BSPs include Ricinus communis RcBSP; Populus trichocarpa PtBSP; Populus deltoids PdBSP; Populus alba PaBSP and PaWIN4; Hevea brasiliensis HbBSP; Manihot esculenta MeBSP; P. trichocarpa $\times$ P. deltoids PtdWIN4 and PtdPNI288; and P. trichocarpa $\times$ P. alba PtaWIN4 and PtaPNI288. The phylogenetic tree was constructed by the neighbour-joining method in MEGA 7.0 software; one thousand replicates were used for the bootstrap test; red frame: JcBSP family members. 


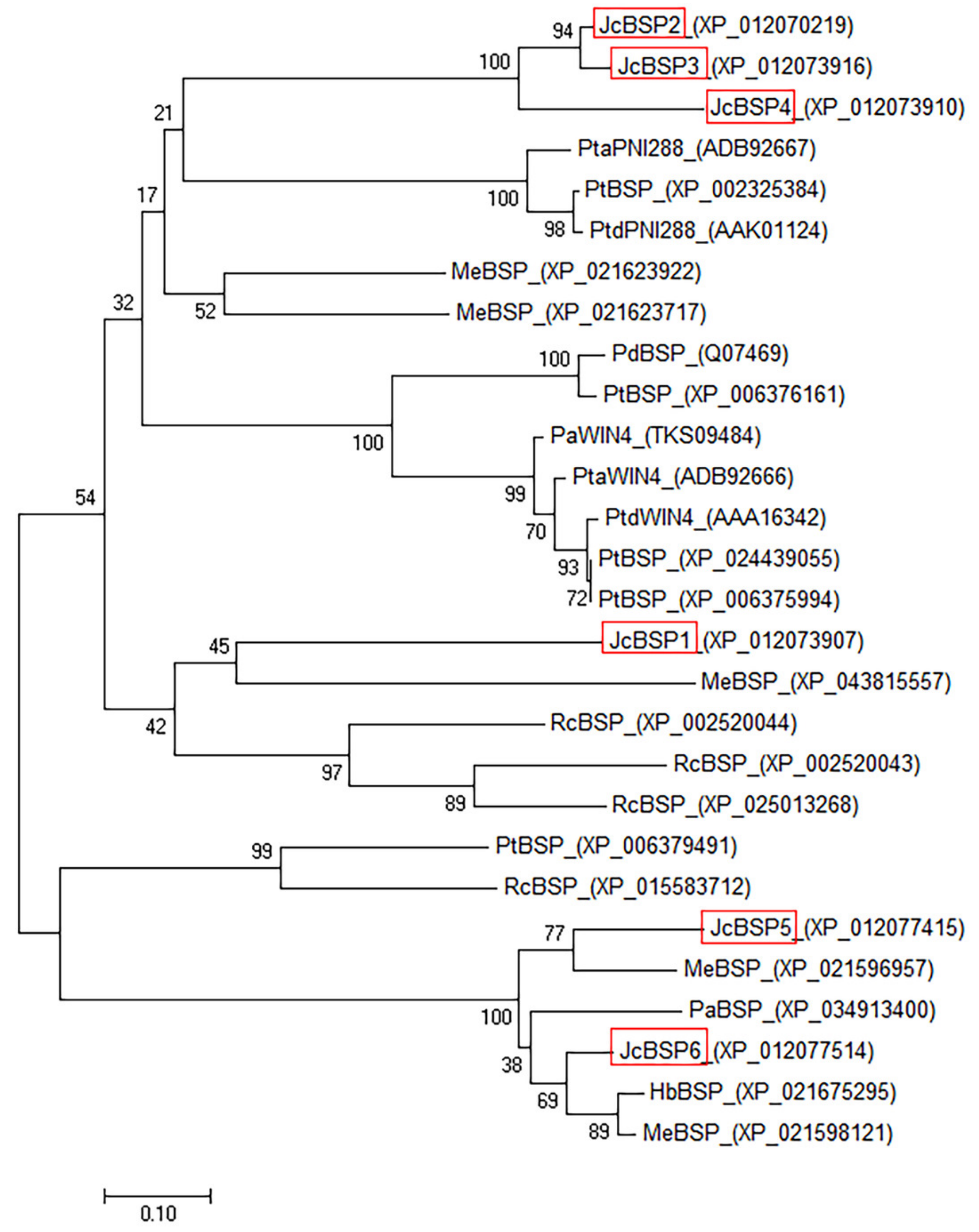


Figure 3

Expression analysis of $J C B S P$ s in various tissues of adult $J$. curcas.

The qRT-PCR results were obtained from three biological replicates and three technical replicates. The values were normalized to the expression of JcActin1. Error bars denote the SD from three biological replicates. $R$, roots; S, stems; SA, shoot apices; $Y L$, young leaves; ML, mature leaves; MF, male flowers; FF, female flowers; Fr, fruits; Se, seeds.
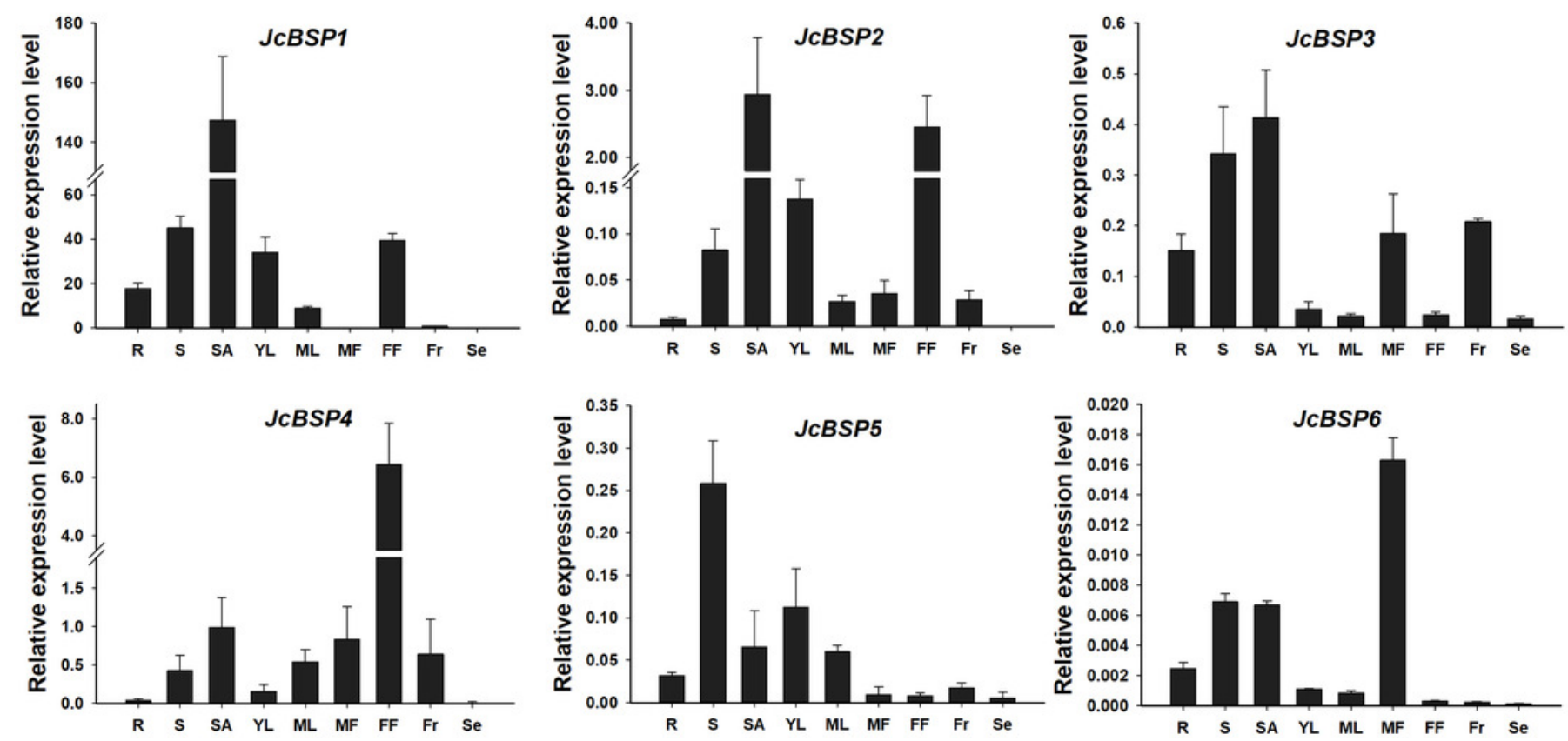
Figure 4

Seasonal changes in total protein concentrations in the stems of adult J. curcas.

(A) Cross section of stems. The red arrow shows the bark and phloem, and the blue arrow shows the xylem and pith. (B) Total protein concentrations of $J$. curcas stems. The results were obtained from three biological replicates.
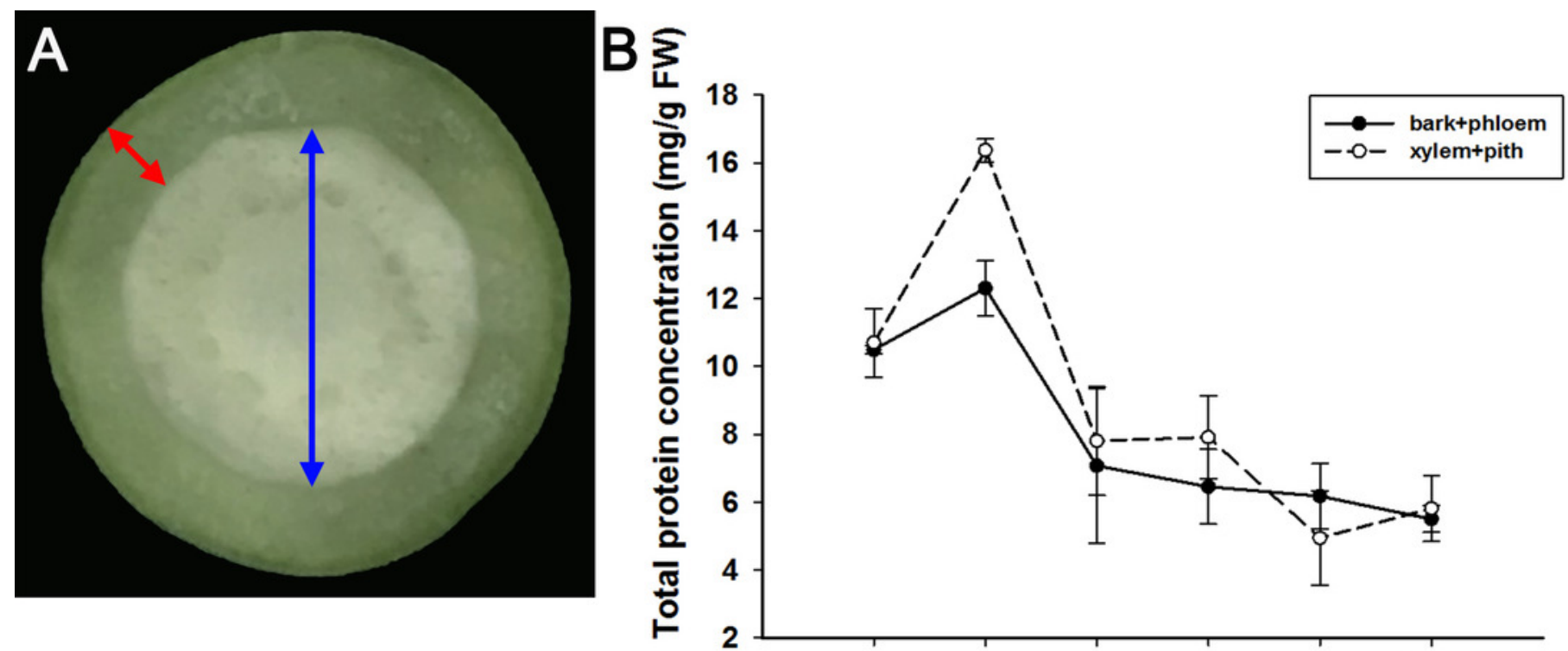

Oct
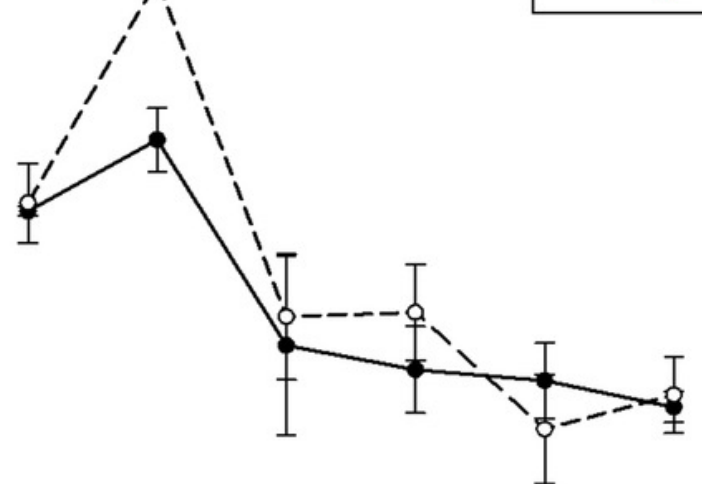

Dec.

Mar. Apr. Jun. Aug. 


\section{Figure 5}

Seasonal changes in JCBSP expression in the two parts of J. curcas stems.

The qRT-PCR results were obtained from three biological replicates and three technical replicates. The values were normalized to the expression of JcActin1. Error bars denote the SD from three biological replicates. 
bark+phloem
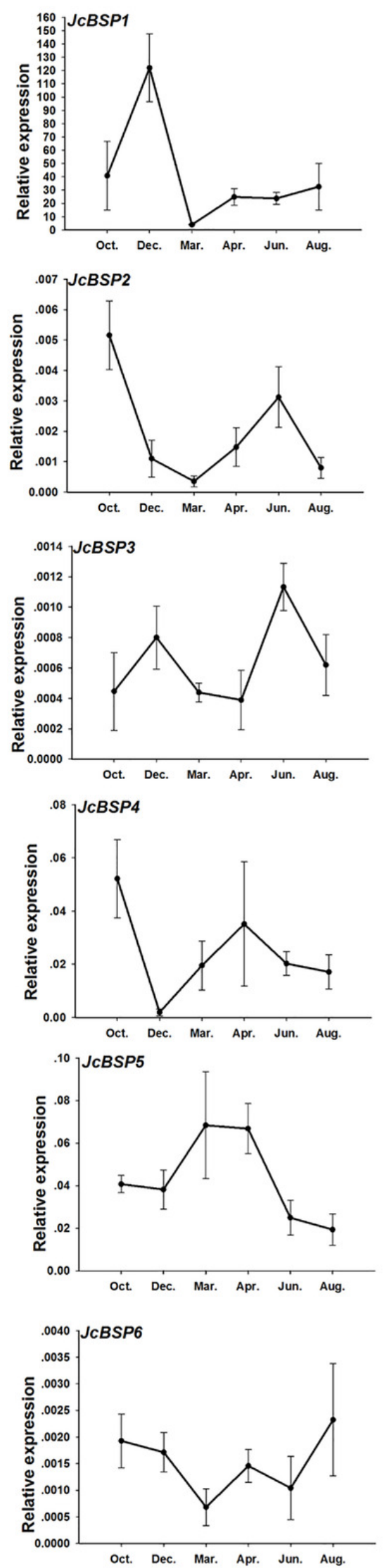

xylem+pith
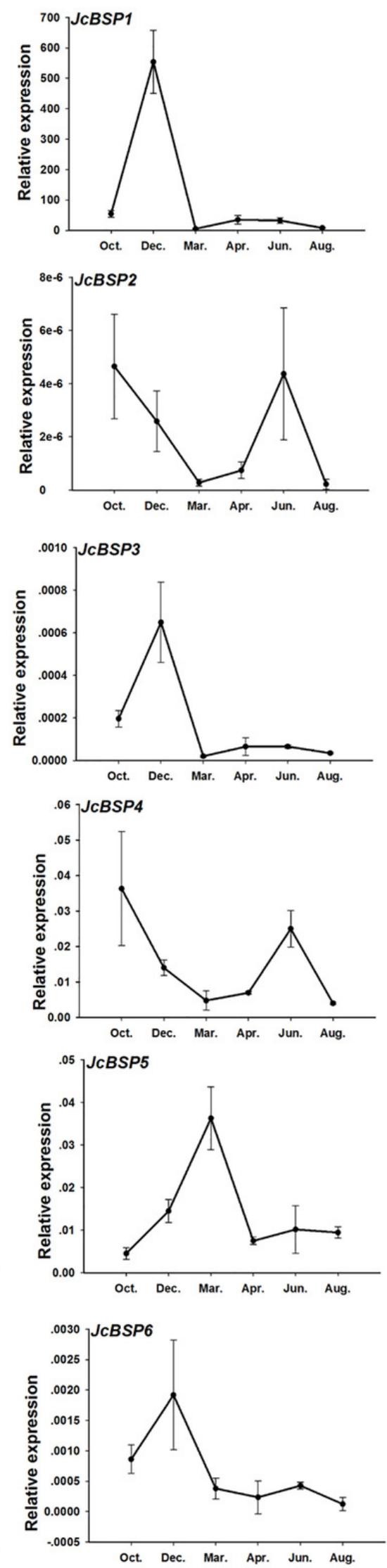
Figure 6

Correlation analysis between the seasonal changes in total protein concentration and $J C B S P 1$ expression in the bark + phloem (A) and the xylem + pith (B).
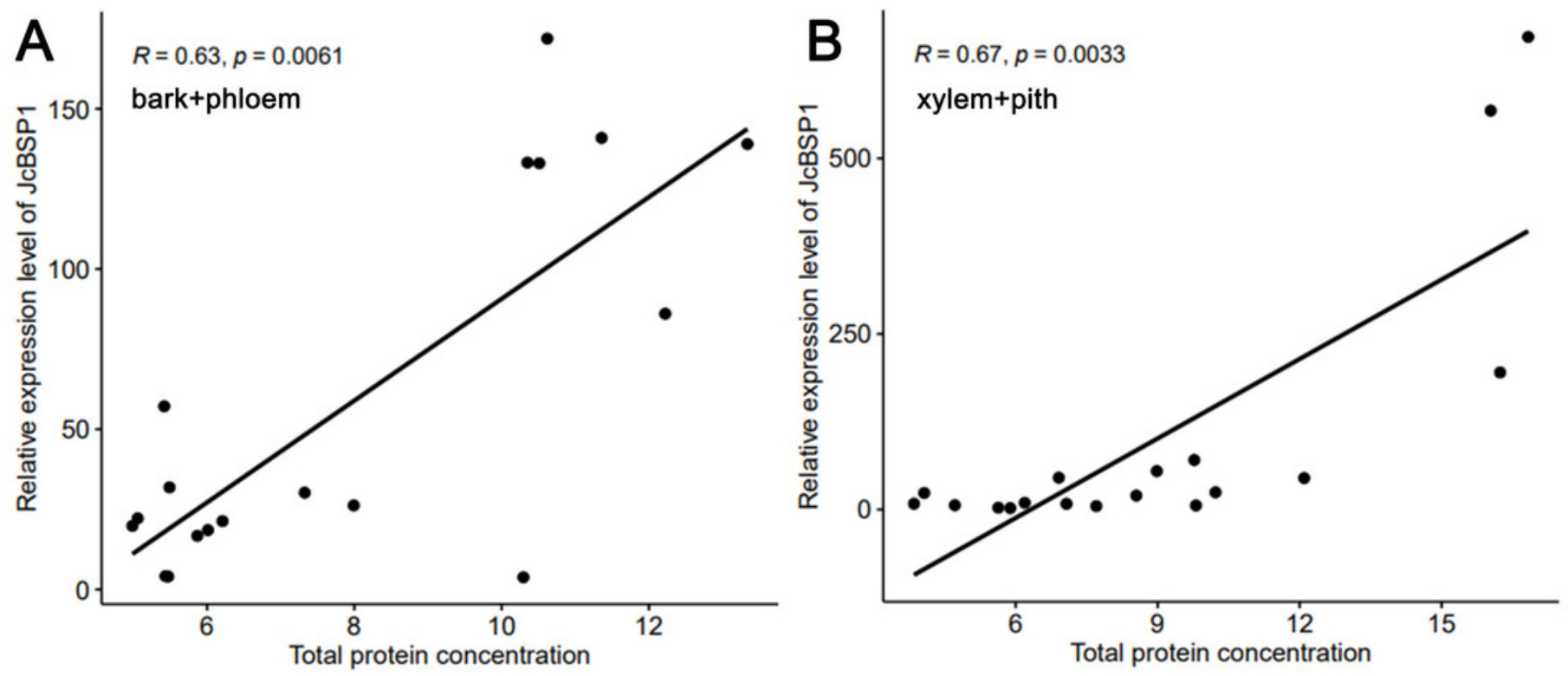


\section{Figure 7}

Changes in JCBSP expression in the leaves of two-month-old J. curcas seedlings treated with $\mathrm{NH}_{4} \mathrm{NO}_{3}$.

(A) J. curcas seedlings treated with different concentrations of $\mathrm{NH}_{4} \mathrm{NO}_{3}$ for 8 weeks. (B) JCBSP expression in response to $\mathrm{NH}_{4} \mathrm{NO}_{3}$ treatment. The qRT-PCR results were obtained from three biological replicates and three technical replicates. The values were normalized to the expression of JcActin1. Error bars denote the SD from three biological replicates. 

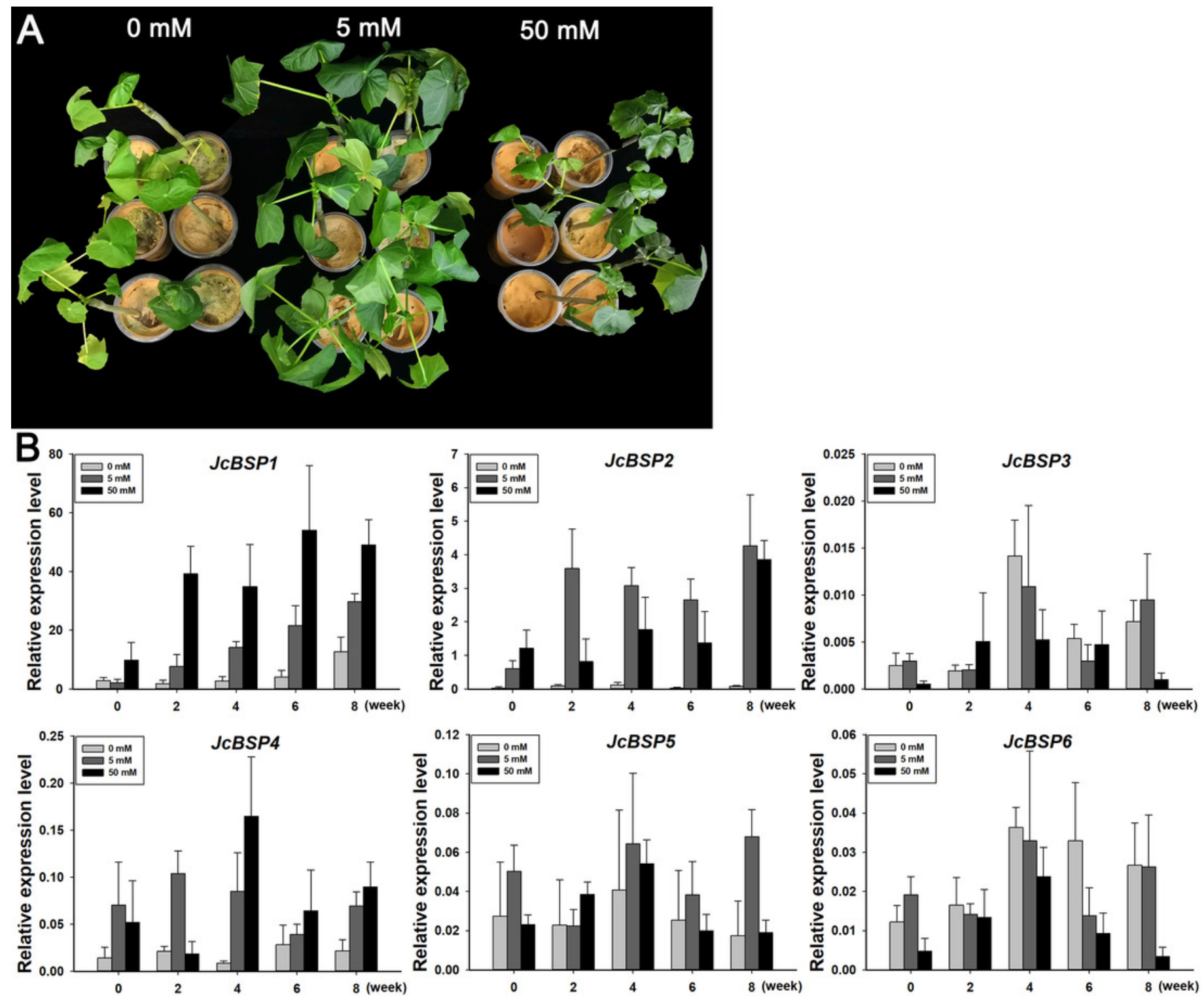


\section{Figure 8}

Phenotypic changes in 35S:JCBSP1 transgenic Arabidopsis.

(A) PCR identification of 35S:JCBSP1 transgenic Arabidopsis. WT, wild-type negative control;

$\mathrm{ddH}_{2} \mathrm{O}, \mathrm{ddH}_{2} \mathrm{O}$ negative control; $\mathrm{P}$, positive control. (B) qRT-PCR analysis of $J c B S P 1$ expression in WT and transgenic Arabidopsis (L4 and L10). The qRT-PCR results were obtained from three biological replicates and three technical replicates. The values were normalized to the expression of AtActin2. Error bars denote the SD from three biological replicates. ( $C$ and $D$ ) Rosette leaves and flowers from WT and transgenic Arabidopsis. ( $E$ and F) Leaf length and width of WT and transgenic Arabidopsis. The values are presented as the means \pm standard deviations $(\mathrm{n}=8)$. Student's $t$-test was used for significance analysis: $* * P \leq 0.01$. 


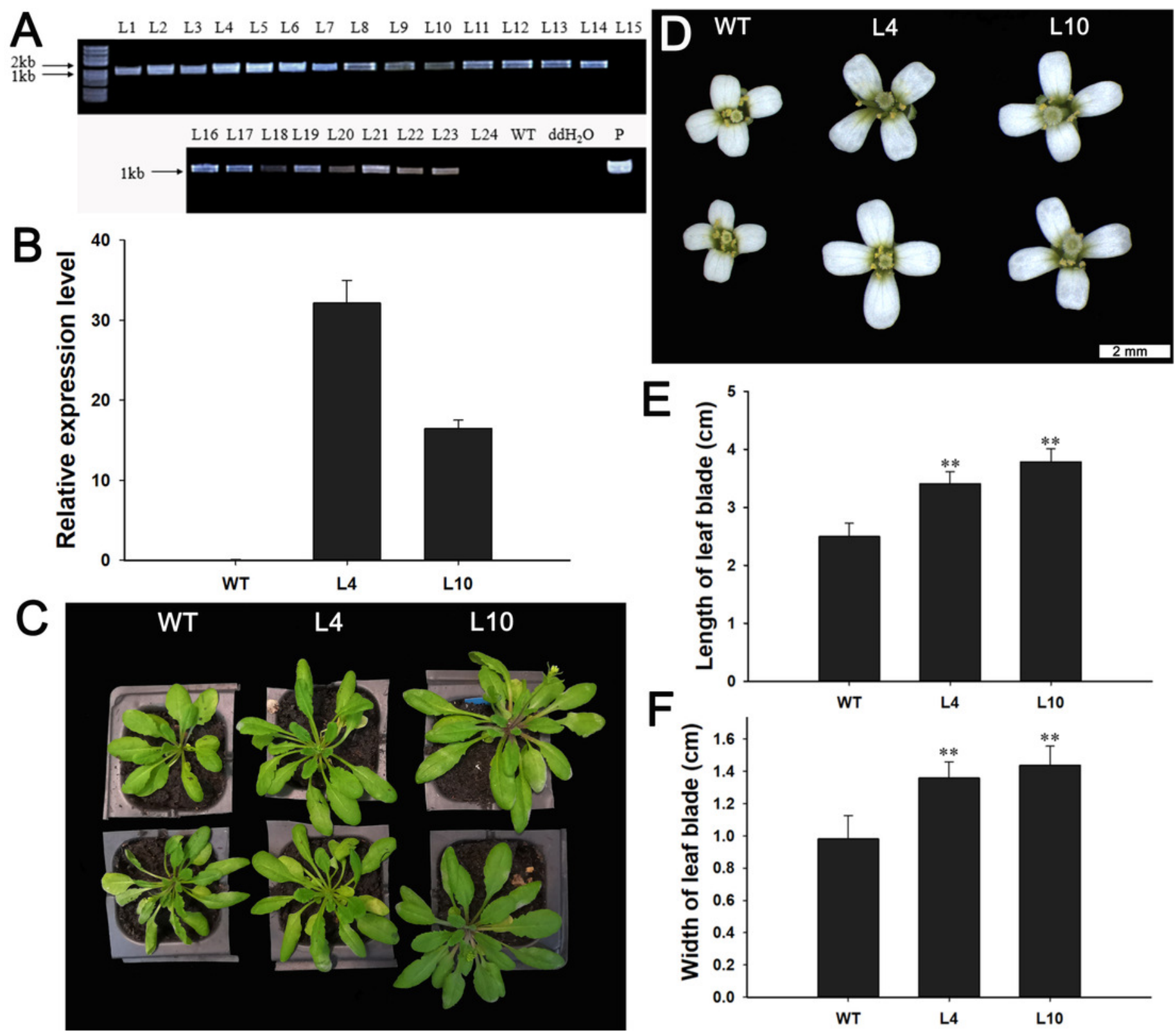




\section{Figure 9}

Overexpression of $J C B S P 1$ increased theseed size, weight, and yield intransgenic Arabidopsis.

Seed size $(A)$, hundred-seed weight $(B)(n=3)$ andseed yield per plant $(C)(n=6)$ were analyzed in WT and transgenicArabidopsis lines L4 and L10.The values are presented as the means \pm standard deviations. Student's $t$-test was used for significance analysis: $* P \leq 0.05$, $* * P \leq 0.01$.

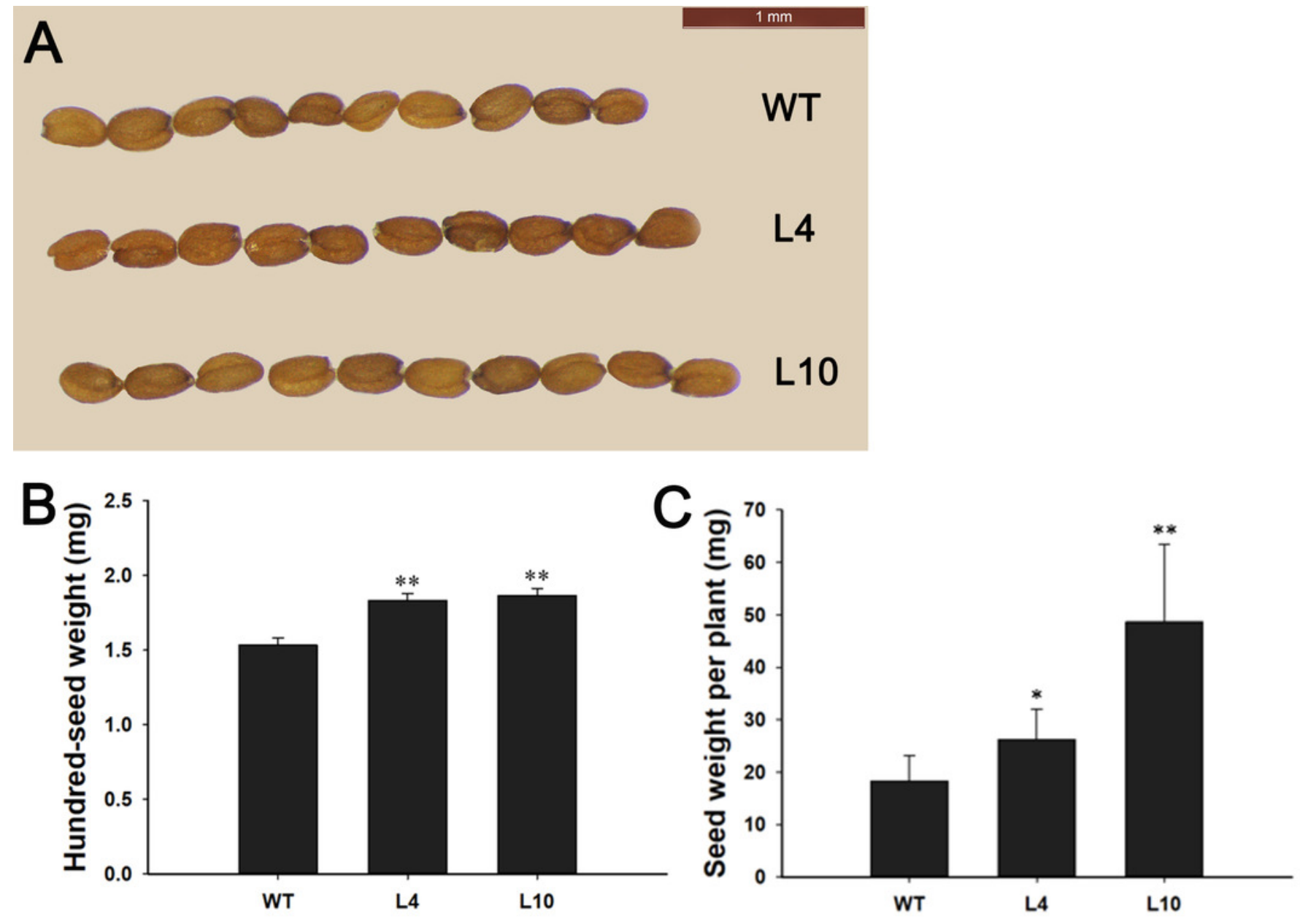

